commodity producers, and do not have any benefits in obtaining state subsidies.

After Ukraine's entrance to the World Trade Organization, the domestic market of organic products risks to face the expansion of foreign manufacturers that operate in much more favorable financial and legal terms.

Thus, in order for the Ukrainian organic product market, barely starting to function, it requires the formation and implementation of the National Management Model, which will consider both the interests of the development of the domestic market and the interests of exports of organic products. Improvement of legislation and structures of certification and supervisory organizations, drawing up a program of financial, informational and marketing support for domestic producers of organic products - these are events, without which the development of the domestic market of organic products in conditions of severe international competition is practically impossible. For Ukraine, the structure of exports of which is raw material, the formation of organic agriculture with an orientation to the country with a developed national market, but the lack of production base is particularly relevant.

DOI https://doi.org/10.30525/978-9934-26-040-7-32

\title{
ПАРТНЕРСТВО УКРАЇНИ З ВИШЕГРАДСЬКОЮ ЧЕТВІРКОЮ У СФЕРІ ЕКОЛОГІЧНОЇ БЕЗПЕКИ РЕГІОНУ
}

\author{
Качурінер В. Л. \\ кандидат юридичних наук, доцент, \\ дочент кафедри міжнародного права та порівняльного правознавства \\ Міжнародного гуманітарного університету \\ м. Одеса, Україна \\ 3 географічної точки зору та стратегічного розташування Више- \\ градської четвірки (V4) має велике значення для України. Польща, \\ Угорщина, Чехія та Словаччина історично сусідні з Україною країни. \\ Вишеградська четвірка має позитивний досвід інтеграції в європейське \\ співтовариство, у встановленні між собою політичного та економічного \\ співробітництва, а також у вирішенні спірних питань.
}


19 листопада 2019 року президент України Володимир Зеленський та прем'єр-міністр Чехії Андрій Бабіш домовились, що Україна посилить співпрацю з Вишеградською групою.

Повертаючись до питання, в якій галузі інтереси V4 в першу чергу збігаються 3 інтересами України, зауважимо, що найважливішою складовою побудови національної безпеки кожної сучасної держави $\epsilon$ охорона навколишнього середовища. Для V4, як і для України, безпека починається саме тут, на європейському екологічному перехресті. Екологічна безпека регіону, де ми живемо, вразлива до нових загроз як від стихійних лих, так і від результатів людської діяльності. Серед сфер, в яких може розвиватися глибоке партнерство України з V4, спільне протистояння екологічним викликам регіону. Сьогодні найнебезпечнішими 3 них $є$ : ситуація навколо Шацьких озер, питання збереження «легенів Свропи» - карпатські ліси тощо [1, с. 91].

У 2012 році Мінськ продовжив промисловий розвиток Хотиславського родовища крейди, розташованого на кордоні з Волинською областю України. Українська сторона попереджає про екологічні наслідки видобутку, оскільки кар'єр може зруйнувати унікальні Шацькі озера, розташовані в 30 км від родовища.

При реалізації планів з розробки Хотиславського крейдяного родовища білоруська сторона керується Національною стратегією сталого соціально-економічного розвитку до 2020 року. Суть екологічної проблеми полягає в тому, що на відстані 250 м від кордону з Україною та 30 км від Шацьких озер в Білорусі активно освоюється родовище піску та крейди. Згідно з проектом, роботи слід проводити на глибині 45 м. Експерти попереджають, що величезна порожнина в землі, що утворилася в результаті цих робіт, може буквально висмоктувати Шацькі озера.

В межах Стратегії транскордонного співробітництва Люблінського воєводства (Республіка Польща), Волинської, Львівської областей (Україна) та Брестської області (Республіка Білорусь) на 2014-2020 роки зазначено, що розвиток міжнародного співробітництва у галузі охорони природи i ландшафту забезпечив можливість створення системи транскордонних охоронних територій на польсько-білоруськоукраїнському прикордонні. Одним з елементів цієї системи є Транскордонна мережа біосферних заповідників, яка має істотне значення з точки зору регіонального планування та регіональної політики, що базується на екологічно збалансованому розвитку.

Однак, господарська діяльність та прагнення людей вдосконалювати умови проживання $\epsilon$ причиною деградації природного середовища. Найбільша деградація навколишнього природного середовища пов'язана 3 забрудненням повітря, води і грунту. Під забрудненням повітря розуміється емісія людиною в повітря твердих, 
рідких або газоподібних речовин у такій кількості, яка може загрожувати здоров'ю людей й негативно впливати на клімат, живу природу, грунт чи воду. Аналізуючи просторовий розміщення емісії забруднень повітря на досліджуваній території, слід зауважити, що вони у великій мірі концентруються при державному кордоні Польщі з Україною та Білоруссю. Це вимагає уваги та внесення цього питання до порядку денного діяльності V4 та України.

Ще одне питання, яке на сьогодні актуальне - проблема неконтрольованого вирубування лісів Карпат ми вважаємо складовою переліку екологічних загроз. Ще одна екологічна катастрофа на Заході країни - повінь, на думку екологів, спричинена масовою та неконтрольованою вирубкою лісів Карпат. Коли в гірських районах $є$ ліс, значний приплив води від дощу або талого снігу повільно стікає з гір у водойми, не викликаючи катастрофи. Але коли гори «лисі» і вода 3 великою швидкістю стікає гірськими схилами по скелях, не зволікаючи, річки швидко розливаються і розливаються по берегах [2].

В результаті вирубки лісів у Карпатах протягом останніх років спостерігаються масштабні повені в західних областях України. Вода, яка дуже швидко стікає в долини, створює масштабні екологічні катастрофи. Сусіди України, Польща, Словаччина та Румунія, вже усвідомили цю небезпеку та припинили комерційне вирубування лісів у Татрах та Карпатах.

3 березня 2010 року в Європейському Союзі набула чинності нова директива про продаж деревини. Вимоги до імпорту стали жорсткішими, і екологи сподівались, що це допоможе зменшити вирубку лісів в Україні. Положення № 995/2010 передбачає новий рівень контролю за імпортом деревини до СС. Іноземні покупці зобов'язані підтвердити походження деревини та засвідчити, що вона зрубана законно. Невиконання цих вимог призведе до штрафу, конфіскації деревини та припинення торгівлі. Посилення контролю за ринком деревини в Європі суттєво зменшило несанкціоноване вирубування лісів Карпат [3].

У 2010 році Україна запровадила спеціальні сертифікати на деревину, що вивозиться за кордон. 3 тих пір обсяг незаконно вивезеної деревини зменшився на $80 \%$. Ще одним стримуючим фактором може бути збільшення штрафу за вирубку лісів. Інвентаризація лісового господарства також матиме позитивний вплив на процеси контролю за вирубкою лісів. Існує проблема уніфікації законодавства: внутрішнє законодавство, яке суттєво відрізняється від європейського, також потребує доопрацювання.

Європейський парламент позитивно вплинув на обсяги незаконних рубок, але водночас встановив високі вимоги до України щодо контролю за переміщенням деревини, що передбачає необхідність ство- 
рення іiї електронного обліку. Таким чином, лише комплексний підхід до справи може виправити ситуацію і сьогодні українські екологи спираються на контроль сусідніх країн, які входять до ЄC, зокрема V4.

Тому компонентами співпраці України з V4 має бути вирішення питань, пов'язаних із Шацькими озерами та Карпатськими лісами. Ці теми слід включити до списку пріоритетів у плані V4, оскільки саме ця організація виступає за захист безпеки, включаючи екологічну безпеку, в європейському регіоні.

\title{
Література:
}

1. Чекаленко Л. Завданння Вишеграда: угорське головування. Співробітництво з краӥнами Вишеградської четвірки як інструмент європейської інтеграчї та модернізачї Украӥни : матеріали міжнародної конференції (3 жовтня 2013 р., м. Ужгород). К. : НІСД, 2014. C. 89-98.

2. Ukraine floods: Why climate change and logging are blamed. URL: https://www.bbc.com/news/world-europe-53233387.

3. Regulation (EU) No 995/2010 of the European Parliament and of the Council of 20 October 2010 laying down the obligations of operators who place timber and timber products on the market Text with EEA relevance. Official Journal of the European Union. L 295. 2010. P. 23-34.

DOI https://doi.org/10.30525/978-9934-26-040-7-33

\section{ПРАВОВИЙ РЕЖИМ ОХОРОНИ ЗЕМЛІ ЯК ОСНОВНОГО НАЦІОНАЛЬНОГО БАГАТСТВА В УКРАЇНІ}

\author{
Носік В. В. \\ доктор юридичних наук, професор, \\ член-кореспондент Національної академії правових наук України, \\ завідувач кафедри земельного та аграрного права \\ Інституту права \\ Київського національного університету імені Тараса Шевченка \\ м. Київ, Украӥна
}

Відповідно до ст. 14 Конституції України земля є основним національним багатством, що перебуває під особливою охороною держави. При цьому у Конституції Україні не розкривається поняття 